\title{
INVESTIGATION OF THE NEED FOR SPECIFIC PROPAGATION MODEL FOR SPECIFIC ENVIRONMENT BASED ON DIFFERENT TERRAIN CHARACTERISTICS
}

\author{
Jide Julius Popoola*, Akinlolu Adediran Ponnle, Yekeen Olajide \\ OlasoJi ANd SAMSON AdEnle OYeTUNJI \\ Department of Electrical and Electronics Engineering, \\ School of Engineering and Engineering Technology, \\ Federal University of Technology, P.M.B. 704, Akure, Ondo State, Nigeria. \\ *Corresponding author: jjpopoola@futa.edu.ng \\ (Received: $9^{\text {th }}$ Dec 2017; Accepted:12 $2^{\text {th }}$ July 2018; Published on-line: $1^{\text {st }}$ Dec 2018)
}

https://doi.org/10.31436/iiumej.v19.i2.886

\begin{abstract}
Owing to their speed of excution as well as their limited reliance on detailed knowledge of the terrain characteristics of the service environments, empirical propagation models have enjoyed general acceptability in the wireless communication research community. However, recent industrial observations show that no single propagation model can best fit all the radio service environments, which led to the hypothesis of specific models for specific environments. In order to scientifically verify this hypothesis, the study presented in this paper investigated the performance of the free space propagation loss (FSPL) model in two different radio environments characterised with different types of obstructions. The investigation was conducted through field strength distribution measurement of two broadcasting radio stations transmitting at $96.5 \mathrm{MHz}$ and 102.3 MHz. The field strength measurement data obtained were analysed. The result of the analysis shows gross disparity between the measured path losses and calculated path losses using FSPL model. The disparity thus necessitates the modification of the FSPL model in order to develop each propagation model for each of the two radio stations employed and their environment. The developed models were then evaluated to ascertain their performances relative to the FSPL model. The performance evaluation results show that the predictions of the developed propagation models vary for each of the two environments. Furthermore, the comparative performance evaluation result of the developed models with similar studies in the literature shows that the developed models perform favourably. The overall result from the developed models confirms the hypothesis that each location requires a specific propagation model for proper radio wave design and quality of signal transmission and reception.
\end{abstract}

ABSTRAK: Kelebihan yang ada pada kelajuan perlaksanaannya dan juga kurang pergantungannya pada butiran terperinci ciri-ciri khusus bentuk rupa bumi di persekitaran servisnya, model penyebaran empirik telah diterima umum dalam komuniti kajian komunikasi tanpa wayar. Walau bagaimanapun, pemerhatian industri terkini menunjukkan tidak ada sebarang model penyebaran yang sesuai bagi semua keadaan servis radio, ini menghala kepada hipotesis keperluan model tertentu pada keadaan servis tertentu. Bagi menentusahkan secara saintifik hipotesis ini, kajian yang dibentangkan dalam kertas ini mengkaji tentang prestasi model kehilangan penyebaran pada ruang bebas (FSPL) dalam dua persekitaran radio berlainan melalui beberapa jenis halangan berbeza. Kajian telah dijalankan ke atas dua stesen radio penyiaran pada frekuensi $96.5 \mathrm{MHz}$ dan $102.3 \mathrm{MHz}$ melalui ukuran sebaran ruang keupayaan. Data ukuran ruang keupayaan telah diperoleh 
dan dianalisa. Keputusan analisis menunjukkan keputusan tidak seragam yang melampau antara ukuran kehilangan laluan dan pada kiraan model FSPL. Ketidaksamaan ini memungkinkan keperluan mengubah model FSPL bagi membangunkan model penyebaran pada setiap dua radio stesen yang digunakan dan persekitarannya. Model yang dibangunkan ini kemudiannya dinilai bagi mengesahkan prestasinya dengan model FSPL. Keputusan penilaian menunjukkan perbezaan pada jangkaan model penyebaran bagi setiap dua keadaan. Tambahan, keputusan perbandingan model yang dibangunkan dalam karya ini adalah serupa seperti kajian lain yang berkaitan. Secara keseluruhannya model yang dibangunkan ini mengesahkan hipotesis bahawa setiap lokasi memerlukan model penyebaran bagi rekaan gelombang radio yang sesuai dan juga kualiti signal penyebaran dan penerimaan.

KEYWORDS: obstructions; propagation mechanisms; path loss; propagation models; inverse square law

\section{INTRODUCTION}

Outdoor natural and man-made obstructions, such as vegetation, rocks, buildings, and cars on radio wave paths do interfere with the radio wave propagation, thus causing radio signal reduction and poor reception. This is because interaction of radio waves with either natural or man-made obstructions reduces its strength. Therefore, in radio communication systems where antennas are employed in transmitting information from the transmitter to the receiver, the channel between and/or around the transmitter and the receiver has a key influence on the quality of the transmitted radio signal. This is because radio wave propagation is highly sensitive to both the properties and effects of the communication channel between and/or around both the transmitting and the receiving antennas [1]. Therefore, when the incoming radio signal impinges on either a natural or man-made obstruction, some of its energy may be reflected back in the same direction. On the other hand, some of its energy may be refracted while some may either be diffracted or scattered. These phenomena, reflection, refraction, diffraction, and scattering, are the basic propagation mechanisms that impact radio wave propagation between transmitter and receiver and cause fluctuations in the received signal's phase and amplitude [2].

In radio communication systems, these fluctuations in the received signal's phase and amplitude are as a result of reduction in or loss of signal strength that propagated from the transmitter to the receiver. The loss that occurred between the transmitter and the receiver in radio communication systems is known as propagation path loss [2-4]. Propagation path loss is defined as a measure of the average attenuation a transmitted signal suffered when it arrives at the receiving end after it has traversed a path of several wavelengths [5]. Thus, its model is used in estimating the signal-to-interference ratio, received signal level, and carrier-to-interference ratio [6].

Basically, as a result of both the complexity and versatility of the radio wave propagation environments, the received signal strength in wireless systems usually changes with time and space. Thus, during wireless systems planning, it is necessary to estimate the average signal that would be received by the receiver(s) located in various areas around the transmitter. This makes efficient path loss prediction an important activity for proper design and maintenance of wireless communication systems. Different kinds of obstructions influence radio wave propagation in a wireless communication channel. For instance, as reported in [7], vegetation plays a significant role in radio wave signal strength reduction in wireless communications. Similarly, within the built up areas, shadowing effects of tall buildings and other natural and man-made obstructions do affect the signal strength of radio 
waves [8]. Likewise, in an indoor environment, man-made obstructions like indoor furniture arrangement and the building's walls do cause radio signal reduction. On the other hand, in an outdoor environment where the tendency of foliage occurring within the vicinity of radio signals, especially in suburban and rural areas, the adverse effect of foliage is inevitable. This is because the presence of the foliage in such areas, where topographic features are much more dominant than buildings, adversely affected radio signal reception [9].

Fundamentally, radio signal reduction or path loss is usually being predicted using propagation models. As reported in [10], a number of radio wave propagation models are available to predict path loss over different types of terrains. These radio wave propagation models are broadly classified into three classes: deterministic, empirical, and stochastic. While the deterministic models make use of the laws governing electromagnetic wave propagation to estimate the received signal power at a specified location, the empirical models are based on observations and measurements alone [11]. On the other hand, stochastic models, according to [11], model the environment as a series of random variables.

A propagation model is defined in [2] as an empirical mathematical formulation for estimating the signal's paths of radio transmission and the connected losses in a given environment based on varying parameters such as the distance between the transmitter and receiver, operating frequency band, and obstacles in the transmission path. It is also defined in [12] as an empirical mathematical formulation for characterization of radio wave propagation as a function of frequency, a function of distance between the transmitting and receiving antennas, and a function of other conditions. It is a very significant tool for the design and development of wireless communication systems. It is useful in both network planning and interference preventive studies as the wireless deployment proceeds. Its accuracy and reliability prediction helps in optimizing the wireless system coverage area, transmitter power efficiency, and the possibility of eliminating interference problems with other transmitter(s) in the vicinity.

There are various propagation models available for predicting the path loss. However, observations have shown that all the existing propagation models available in literature cannot be generalized to different environments $[10,13]$ as suitability of the models differs for different environments. This necessitates the proposal made in [13] that specific models need to be developed for specific environments. Therefore, the primary focus in this paper is to technically investigate this proposal made in [13]. The study presented in this paper was also motivated by the encouragement given by the International Telecommunications Union Radiocommunication Section (ITU-R), which reported in [14] that scientists and engineers should carry out research that would lead to the development of signal propagation models suitable for their respective localities. It was on this premise and the proposal in [13] that the study presented in this paper was conceived to investigate the proposal raised as well as developing suitable propagation models for VHF broadcast systems in Lagos State and Ondo State, Nigeria.

In achieving this objective, some existing radio propagation models were briefly reviewed. Field measurements were conducted using two broadcasting stations as case studies. The field measurement results obtained were later analyzed. Detailed information on the analysis results that necessitate the development of new propagation models for each of the locations used as case studies are presented in this paper. In enhancing logical presentation of the study in this paper, the rest of the paper is organized as follows. In section 2 , a brief review on related works on radio wave propagation models was carried out. Section 3 explains in detail the method used to carry out the study presented in this paper. 
The results obtained were presented and discussed in section 4 while the paper is concluded in section 5 .

\section{REVIEW OF SOME RADIOWAVE PROPAGATION MODELS}

Researchers in most countries of the world have developed and published the propagation models for various parts of their countries. Selected among these propagation models are Okumura, Hata, Okumura-Hata, Free Space Propagation, Longley-Rice, COST231, Egli, International Telecommunication Union (ITU) and COST 231 Walfisch-Ikegami (W-I). Brief reviews of FSPL and Egli models are presented, upon which the models in this study are based

\subsection{Egli Model}

This propagation model is an example of a terrain model for radio frequency (RF) propagation. As reported in [15], the model was first introduced by John Egli in 1957. The model, as reported in [16] is based originally on the free space propagation model. It is applicable for path loss prediction at frequencies from $40 \mathrm{MHz}$ to $900 \mathrm{MHz}$ with linking distance between the transmitter and receiver less than $60 \mathrm{~km}$. As reported in [17], the model is one of the best known statistical models for estimating radio wave propagation loss in either urban or rural environments. The model was developed from actual data on UHF and VHF television transmissions in several large cities. The model is based on plane earth propagation. Authors in [15] observed that there was a tendency for the median signal in a small area to follow an inverse fourth-power law with distance from the transmitter. The mathematical expression for the Egli's propagation path loss prediction model is expressed in $[16,17]$ as;

$$
L_{50}(d B)=20 \log _{10} f+40 \log _{10} d-20 \log _{10} h_{t}+ \begin{cases}76.3-10 \log _{10} h_{r} ; & h_{r} \leq 10 \\ 85.9-20 \log _{10} h_{r} ; & h_{r} \geq 10\end{cases}
$$

where $L_{50}(d B)$ is the 50th percentile or median path loss, $f$ is the operating frequency from $40 \mathrm{MHz}$ to $900 \mathrm{MHz}, h_{t}$ is the transmitter antenna height, $h_{r}$ is the receiver antenna height and $d$ is the distance between the transmitter and receiver.

\subsection{Free Space Propagtion Model}

This model, according to $[17,18]$, is the primary model being used to predict received radio wave signal strength when there is a clear and unobstructed line-of-sight path between the transmitter and the receiver. In the free space propagation model, the radio wave is neither reflected nor absorbed [19]. Thus, the free space propagation model is a typical propagation model to predict the path loss in signal strength of a propagating radio wave that results from a line-of-sight path through free space without obstructions to cause absorption, refraction, reflection, diffraction, or scattering. Microwave links and satellite communications are typical examples of wireless communication systems that can be modeled as free space propagation links [19]. For this propagation model, the received signal power, $P_{r}$, at distance, $d$, from the transmitter is expressed in [20] as;

$$
P_{r}(d)=\frac{P_{t} G_{t} G_{r} \lambda^{2}}{(4 \pi)^{2} d^{2}}
$$

where $P_{t}$ is the power of the transmitter, $G_{t}$ is the gain of the transmitter, $G_{r}$ is the gain of the receiver, $\lambda$ is the signal wavelength and $d$ is the distance between the transmitter and 
the receiver. All the parameters in equation (2), except the distance, $d$, are all system constants.

The fundamental relationship, known as the free space or Friis equation, is derived from equation (2) as;

$$
\frac{P_{r}(d)}{P_{t}}=G_{t} G_{r}\left(\frac{\lambda}{(4 \pi) d}\right)^{2}=G_{t} G_{r}\left(\frac{v}{4 \pi f d}\right)^{2}
$$

where $v$ is the velocity of radio waves. Equation (3) shows that free space propagation obeys an inverse square law, which is a principle that expresses the manner with which radiant energy propagates through space. The law states that the power intensity per unit area from a point source transmitter varies inversely according to the square of the distance from the source. As a result of the inverse square law, the path loss in free space propagation prediction increases with the square of the transmission frequency. Similarly, both the path loss and received power increase and fall, respectively, by $6 \mathrm{~dB}$ when the operating frequency and range are doubled. Thus, high gain antennas can be used to compensate for this loss [21].

Fortunately, design for high-gain antennas at frequencies in and above the VHF band is relatively easier. This provides a remedy for point-to-point or fixed wireless links using isotropic antennas, usually used in VHF and UHF links. Thus, for two isotropic antennas $\left(G_{t}=G_{r}=1\right)$ with a distance, $d$, between them, the free space path loss is expressed mathematically in $[20,22,23]$ as;

$$
L_{p}(d B)=32.44+20 \log _{10} f+20 \log _{10} d
$$

where all the parameters are same as earlier defined.

When the transmitting antenna is located in free space, it has a gain, $G_{t}$, in the direction toward a receiving antenna. Thus the power density, $W$, at a distance, $d$, in a specified direction is expressed in [21] as;

$$
W=\frac{P_{t} G_{t}}{4 \pi d^{2}}=\frac{E^{2}}{\eta}
$$

where $E$ is the electric field strength and $\eta$ is the characteristic wave impedance of free space.

Since it is convenient to write the expression for the electric field strength at a known distance from the transmitting antenna than the power density or power per unit area [21], equation (5) can be expressed as;

$$
\frac{E^{2}}{120 \pi}=\frac{P_{t} G_{t}}{4 \pi d^{2}}
$$

This implies that;

$$
E=\frac{\sqrt{30 P_{t} G_{t}}}{d}
$$

As a result of the convenience of expressing the electric field strength for free space, the free space propagation model, Eq. (7) was employed as the model propagation for this study. The model performances in the two environments where this study was conducted were 
evaluated and compared with results obtained from measured data. The results of the comparative analysis for the two radio wave propagation environments were used to verify the hypothesis investigated in the study presented in this paper. Detailed information on the methodology involved in carrying out the study is presented in the next section of this paper.

\section{METHODOLOGY}

The study presented in this paper was conducted using two radio broadcasting stations. The first broadcasting station is Ondo State Radiovision Corporation (OSRC), which is owned by the Ondo State Government, while the second broadcasting station is Radio Continental, which is a privately owned broadcasting station situated in Lagos State. The two stations in Nigeria are both frequency modulation (FM) stations operating in VHF bands. In carrying out this study, the methodology involved is divided into three stages: the Data collection and estimation stage; the Propagation model development stage; and the Evaluation stage. While detailed information on the third stage is presented in Section 4, the detailed information on each of the first two stages is presented in the following subsections.

\subsection{Data Collection and Estimation Stage}

In this stage, relevant data required for the study were collected. The first class of data collected was the basic operating parameters of the two broadcasting stations, which are presented in Table 1. The second class of data required was measured using different instruments and materials. The two instruments used were BC 1173 field strength meter and global positioning system (GPS) meter known as Germin GPSMAP78s shown respectively in Fig. 1(a) and Fig. 1(b), respectively. Similarly, the two main materials used in gathering the second class of data for the study were the maps of the two primary service areas of the two broadcasting stations and RadioWORKS software. Four cardinal routes were created for each of the stations, where the signal strength values were measured. The field measurement requires the physical presence of the investigators in the various locations where the experimental signal strength data were measured. The BC 1173 field strength meter was used to measure the electric field strength of the transmitted radio signal at each location along the different routes while the coordinates of each location where the signal strength values were measured were determined with the aid of the global positioning system (GPS) meter. The experimental data were recorded in multiples to achieve a high degree of accuracy. The typical characteristics of each of the service areas of OSRC and RC broadcasting stations are shown in Fig. 2(a) and Fig. 2(b), respectively.

In addition, both the collected and measured data were used in the brief analysis conducted at this stage. The analysis involved estimation of the path loss encountered in all the four routes for each station. The essence of the estimation was to determine any disparity in the path loss along each route using the free space path loss model and the calculated path loss obtained using the measured value in each route. Only one typical analytical result, out of four, for each of the routes employed for OSRC and RC respectively is presented in Fig. 3 and Fig. 4 due to limited space. 
Table 1: The Radio broadcasting stations' parameters

\begin{tabular}{lll}
\hline \multirow{2}{*}{ Parameter } & \multicolumn{2}{l}{ Broadcasting Stations } \\
\cline { 2 - 3 } & OSRC FM & RC FM \\
\hline Site Coordinates & Long. $7.2571^{0} \mathrm{~N}$, Lat. 5.2058 $\mathrm{E}$ & Long. $6.5962^{0} \mathrm{~N}$, Lat. $3.3918^{0} \mathrm{E}$ \\
Location & Akure, Ondo State & Ketu, Lagos State \\
Operating frequency & $96.5 \mathrm{MHz}$ & $102.3 \mathrm{MHz}$ \\
Bandwidth frequency & $200 \mathrm{kHz}$ & $200 \mathrm{kHz}$ \\
Transmitter power & $35.0 \mathrm{~kW}$ & $25.0 \mathrm{~kW}$ \\
Effective radiating power & $12.5 \mathrm{~kW}$ & $17.5 \mathrm{~kW}$ \\
Antenna gain & $85.6 \mathrm{~dB}$ & $86.5 \mathrm{~dB}$ \\
Antenna polarization & Circular & Circular \\
Antenna type/model & Yagi-Uda & Yagi-Uda \\
Antenna Maximum height & $150 \mathrm{~m}$ & $150 \mathrm{~m}$ \\
Maximum elevation & $300 \mathrm{~m}$ & $17 \mathrm{~m}$ \\
\hline
\end{tabular}

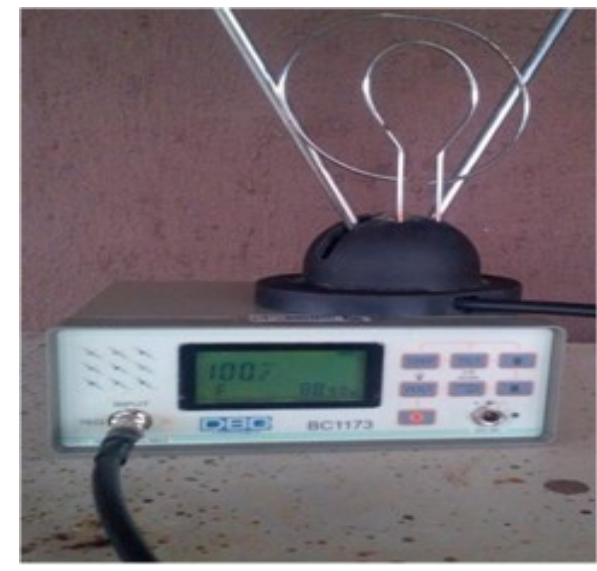

(a)

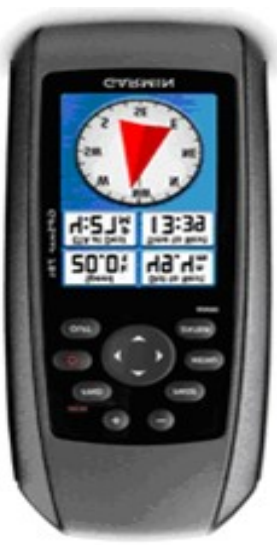

(b)

Fig. 1: Pictures of (a) Field Strength and (b) GPSMAP78s GPS Meters used.

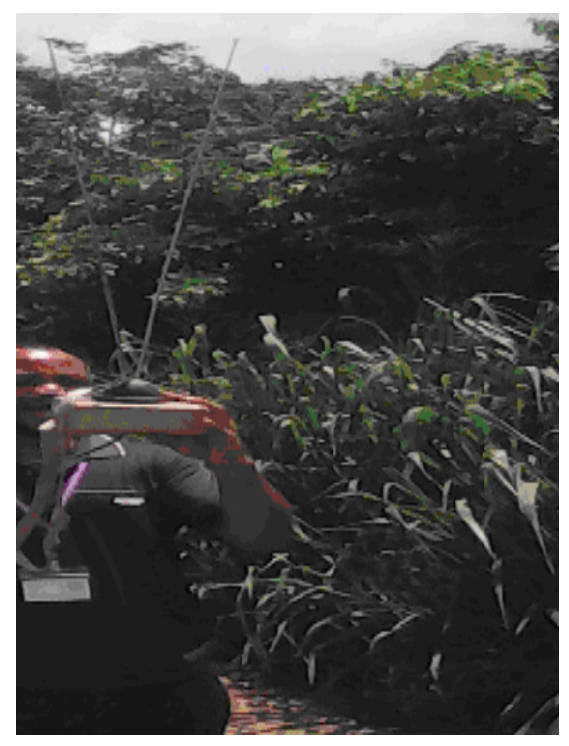

(a)

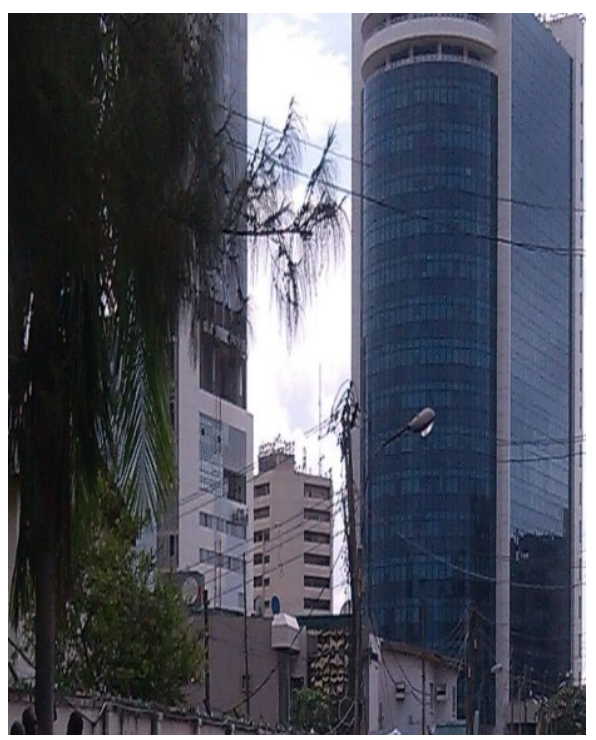

(b)

Fig. 2: Obstruction characteristic of (a) ORSC and (b) RC service environments. 
The obtained results, as shown in Fig. 3 and Fig. 4, show that there is a disparity between the path losses estimated using the FSPL model and the calculated path losses obtained based on the measurement conducted. The losses predicted by the FSPL are higher than the actual losses the radio signals from the stations really experience. This indicates that there is need to develop appropriate models for each route and the entire service areas for each of the radio stations.

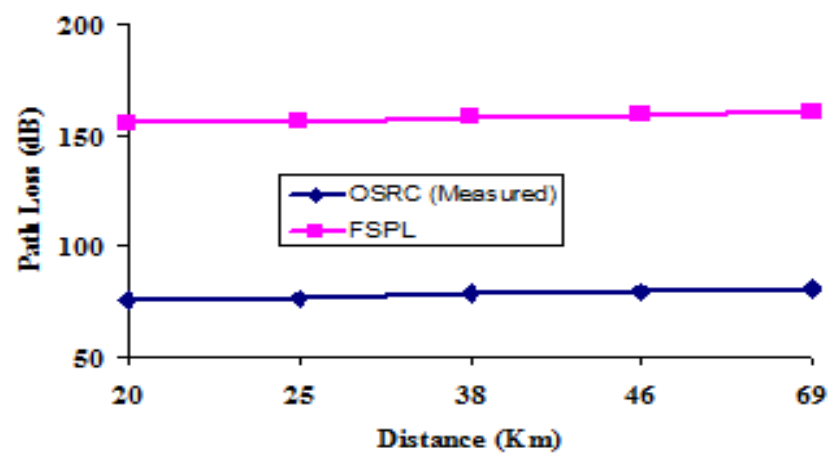

Fig. 3: Typical disparity in FSPL and estimated path loss for OSRC.

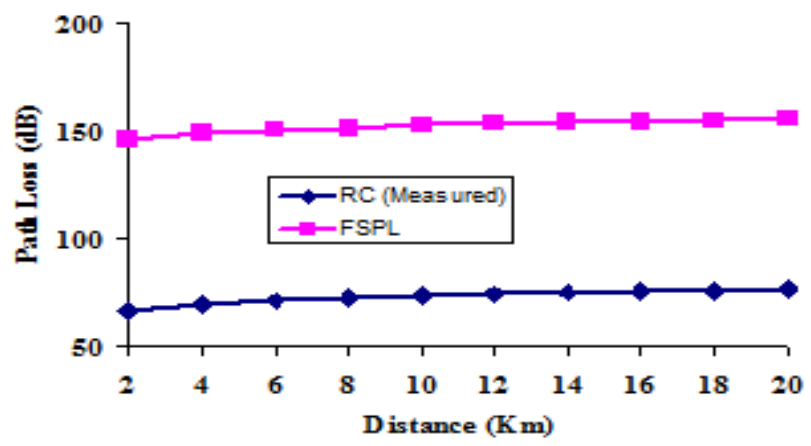

Fig. 4: Typical disparity in FSPL and estimated path loss for RC.

\subsection{Propagation Model Development Stage}

Having observed that there is wide disparity between the measured and the predicted FSPL model losses, it is necessary to develop propagation models for each of the routes considered for each broadcasting station. A least square regression test method was employed to develop the proposed propagation model because the measurements obtained along the four routes reveal a linear relationship between the estimated path loss from the coverage area and corresponding line of sight distance. The overall average value of the least square regression analysis for the four routes finally formed the developed model. The least square test plots for the four routes for OSRC are presented in Fig. 5 while the corresponding plots for the four routes for RC are presented in Fig. 6. From the result, the multiple R shows the correlation between the points and line of best fit which is between the ranges of 0.98-0.94 for all routes considered. Also, $\mathrm{R}$ square shows the percentage of points that fall on the straight line, which is between $98 \%$ and $82 \%$. The coefficient of the $\mathrm{x}$-variable is the slope at the intercept point on the line across the path loss axis. Hence, coefficients of the $x$-variable and the intercept were used to develop the equation for the path loss.

From Fig. 5, the obtained path loss propagation model for Route A is $73.68423+$ $0.000108 \mathrm{~d}$ where $\mathrm{d}$ is the distance in kilometers $(\mathrm{km})$. The corresponding obtained path 

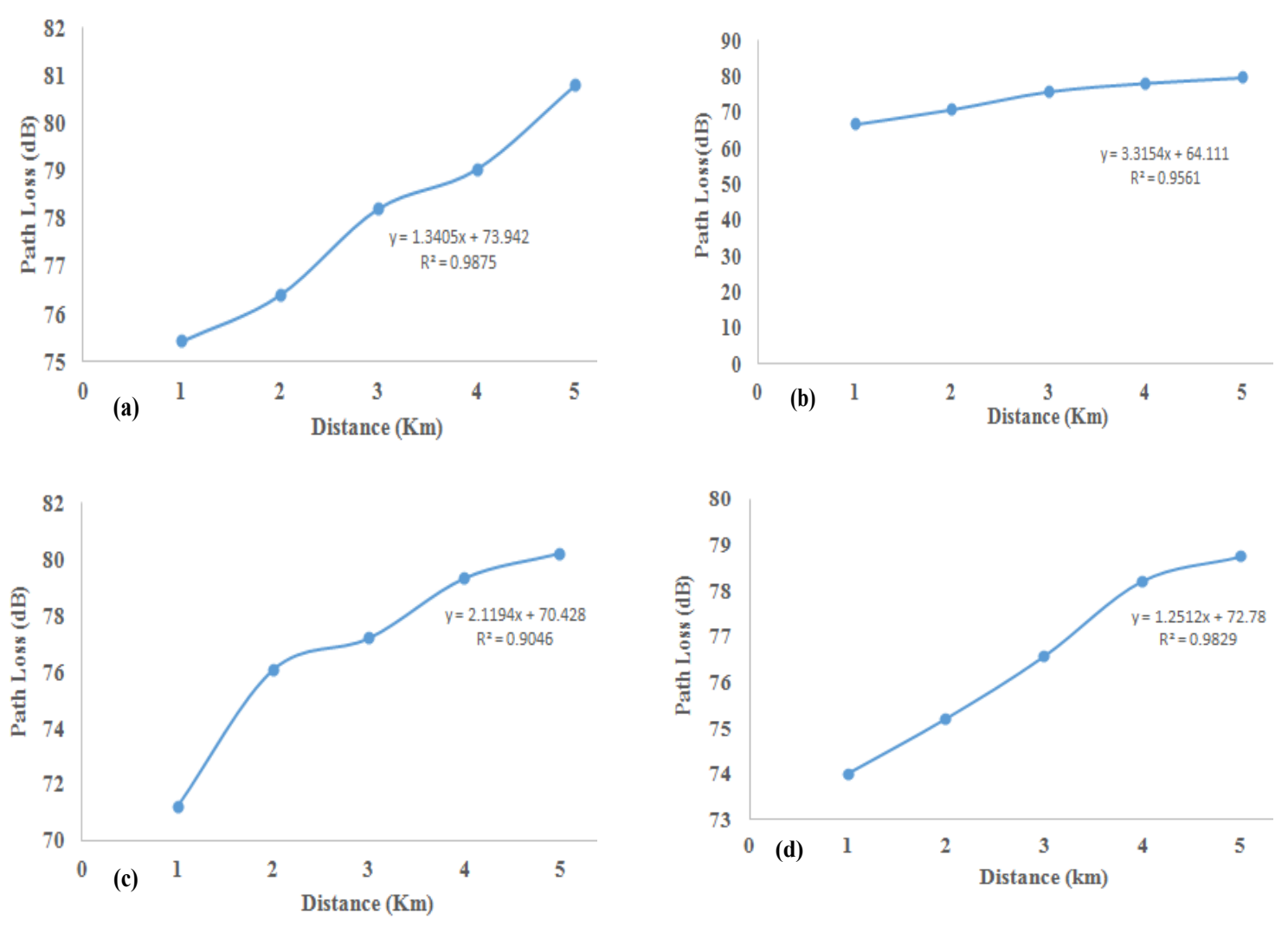

Fig. 5: Regression plots for OSRC Routes A-D model development.
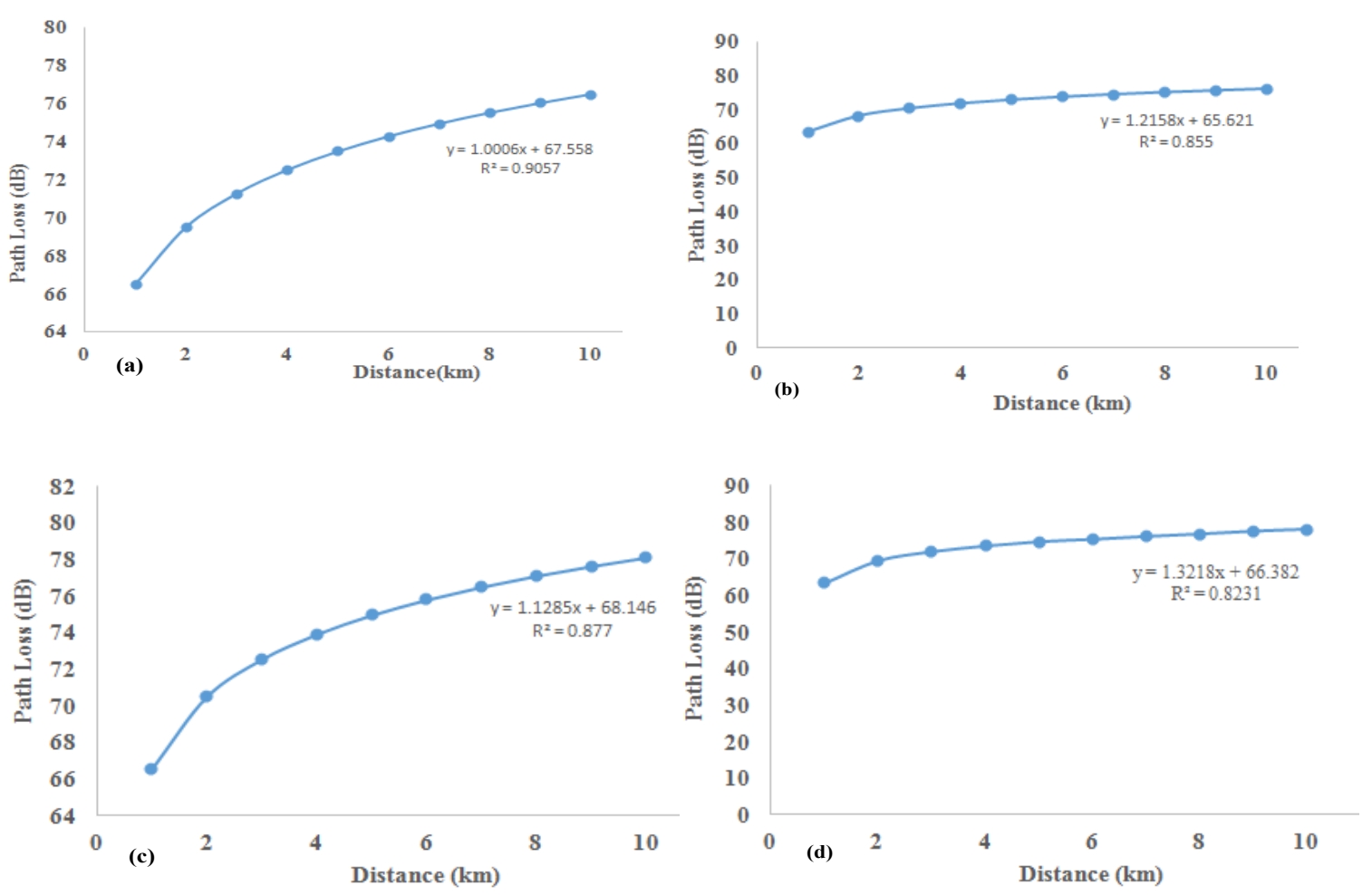

Fig. 6: Regression plots for RC Routes A-D model development. 
loss models for Route B, Route C, and Route D are $68.21458+0.000249 \mathrm{~d}, 71.29911+$ $0.000162 \mathrm{~d}$, and $71.98258+0.000162 \mathrm{~d}$, respectively. The overall obtained path loss propagation model developed, which is the average value of the four routes, is expressed mathematically as $71.29513+0.0003405 \mathrm{~d}$. Similarly, from Fig. 6, the obtained path loss propagation model for Route $\mathrm{A}$ is $67.55847+0.0005 \mathrm{~d}$ where $\mathrm{d}$ is the distance in kilometers $(\mathrm{km})$. The corresponding obtained path loss models for Route B, Route C, and Route D are $66.22881+0.000608 \mathrm{~d}, 68.5224+0.000376 \mathrm{~d}$, and $67.31792+0.000446 \mathrm{~d}$, respectively. The overall obtained path loss propagation model developed is expressed mathematically as $67.4069+0.0004825 \mathrm{~d}$. These respective obtained path loss propagation models are used to predict the path loss for the coverage areas of the stations. The least square regression was used for predicting the relationship between the path loss and distance because of its capability to minimize the sum of the squares of errors between the observed values and the fitted values provided by the developed model.

The effectiveness of the two overall developed propagation path loss models is finally evaluated by comparing their respective performance with the FSPL model. In validating the performance of the developed models, their respective results are equally compared with result of a related study in surveyed literature. The performance evaluation results obtained and further analysis results obtained from the field measurement conducted are presented and discussed in next section.

\section{RESULTS AND DISCUSSION}

This section is devoted to the obtained results presentation and discussion. The section is divided into two subsections. In the first subsection, the results obtained during the conducted field measurements were analyzed. In the second subsection, the comparative performance evaluation test carried out on the developed propagation models for the two broadcasting stations and free space path loss model were presented and discussed. Details on each subsection as well as their respective importance are presented and discussed.

\subsection{Comparative Effects of Dissimilar Obstructions on Radio Signals}

In this subsection, the data obtained during the field measurements conducted were analyzed using RadioWORKS software. The analysis provides the typical obstruction levels that the radio signals from the two radio stations undergo or experience in each of their respective service areas. Only one typical analytical result, out of four, for each of the routes employed for OSRC and RC respectively is presented in Fig. 7 and Fig. 8 due to limited space. Figures 7 and 8 show the line of sight plots between the transmitter and the receiver. The spikes where the elevation line crosses the line of sight in Fig. 7 show the effect of obstructions, which are predominantly rock, hill and tree, in OSRC service areas. The results thus show that the vegetation and other natural obstructions such as hills and rocks that characterized the service areas of OSRC, as shown in Fig 7, have profound negative effects on OSRC's radio signal when compared with high rise buildings, which characterized RC service areas, as shown in Fig. 8. This degree of disparity between obstructions constituted by vegetation and high rise buildings in the two service areas as reported in [24] is because fixed-size obstacles such as foliage or tree trunks usually cause higher blockage of the Fresnel clearance zone. Thus, according to [9], knowledge of propagation effects due to foliage is essential in order to establish a reliable near line-of-sight link. The results also buttress observation in [9] that besides terrain and man-made blockages, signal degradation due to vegetation must be considered during the planning of fixed terrestrial communication links for efficient information transmission in fixed communication systems. 

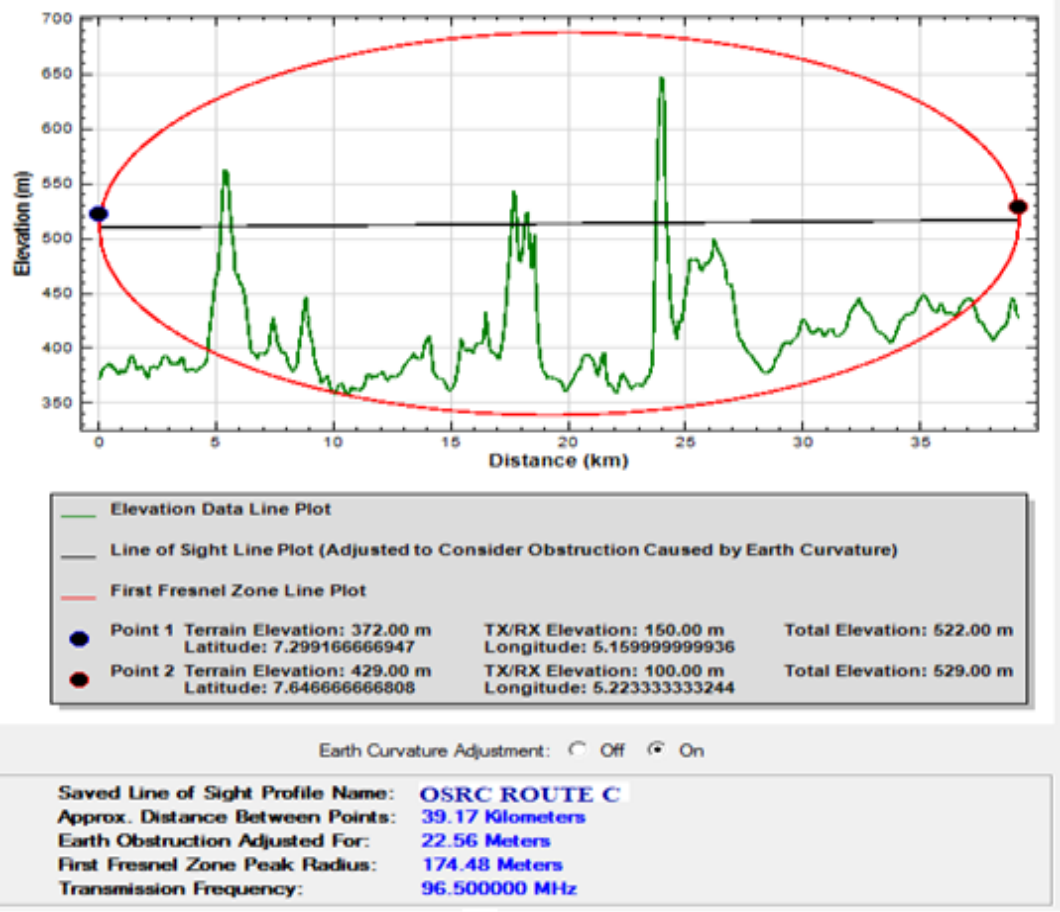

Fig. 7: Typical obstruction level in OSRC service area.
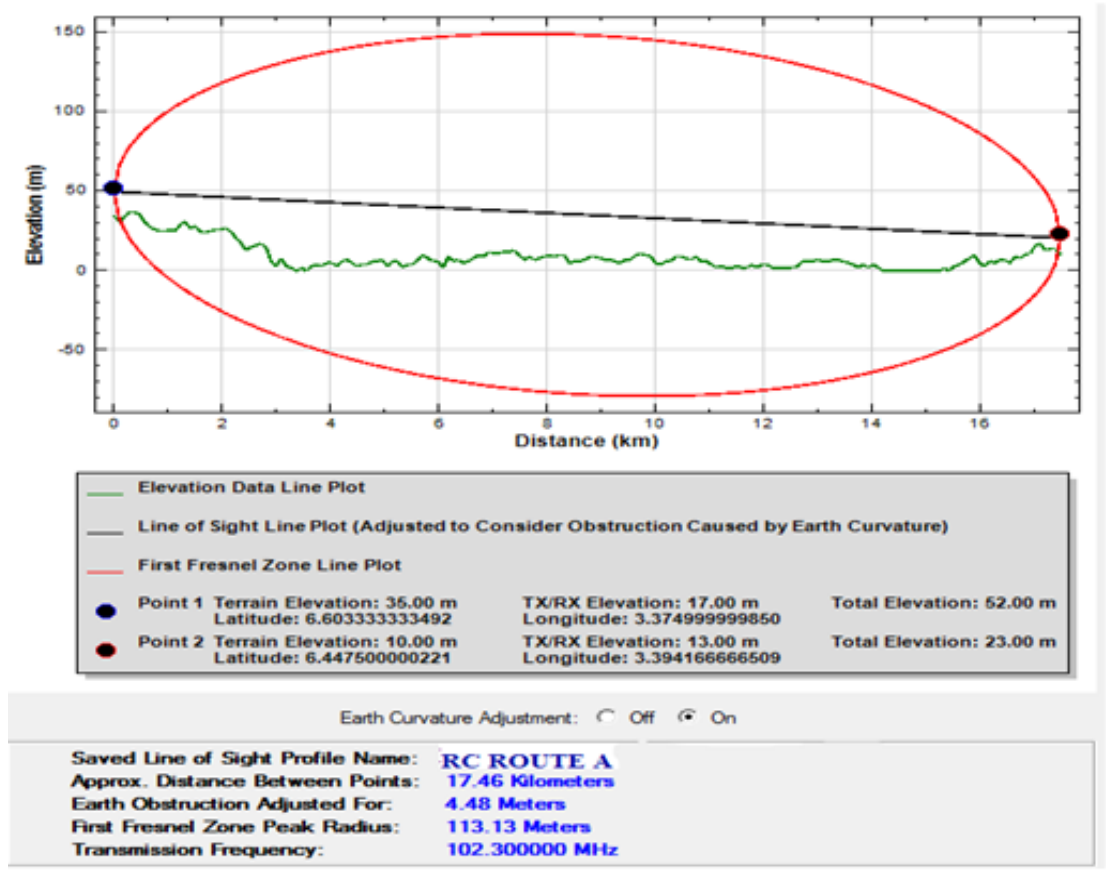

Fig. 8: Typical obstruction level in RC service area.

The results, therefore, show clearly that vegetation, which is an inherent component of most outdoor environments in a forested region like Nigeria, has adverse effect on radio propagation. Thus, as shown in Fig. 7, every location where the elevation data plot crosses the line of sight indicates an adverse effect the obstruction constitutes on the radio signal. The crosses are prominent with OSRC service areas due to fact that the areas are in a region covered in vegetation. The vegetation causes radio signal attenuation in OSRC service areas primarily due to scattering and absorption caused by both leaves and branches of the trees 
dominant in the areas. On the other hand, Fig 8, where the elevation data plots do not cross the line of sight, does not indicate that the RC radio signal is attenuation-free but the RC signal in all the routes are on line of sight (LOS) without obstruction. Basically, location division to either LOS or non-line of sight (NLOS) propagation condition is made according to clearance of the first Fresnel zone. Thus, it means that $60 \%$ of the first Fresnel zone in $\mathrm{RC}$ service areas is clear of any obstructions while at least $60 \%$ of the first Fresnel zone in OSRC service areas is not clear of obstructions.

\subsection{Comparative Performance Evaluation of the Developed Models}

In this subsection, the two developed propagation models were evaluated by comparing their performance with that of the FSPL. The result obtained is presented graphically in Fig. 9, which shows that the path loss predictions by the FSPL model in the two service locations are relatively higher when compared with the prediction results from the developed models. This indicates that the existing FSPL model is not applicable for either of the studied broadcasting stations. The comparative performance result also shows that the prediction results of the developed models differ for the two broadcasting stations. The overall comparative result thus buttress the finding in [25] that there is no single or universal propagation model that exactly fits all terrains, applications, and environments. Similarly, the comparative performance evaluation result has clearly shown the finding in [26], that a radio propagation model that gives an acceptable prediction in one scenario might not be suitable in another scenario. Furthermore, the performance evaluation result of the two developed path loss propagation models for this study also shows that their predicted path losses are lower than the corresponding predicted values by the FSPL existing model. This establishes the correctness of the hypothesis in $[10,13]$ that there is need to develop specific propagation models for specific locations to enhance efficient information transmission and reception in wireless communication.

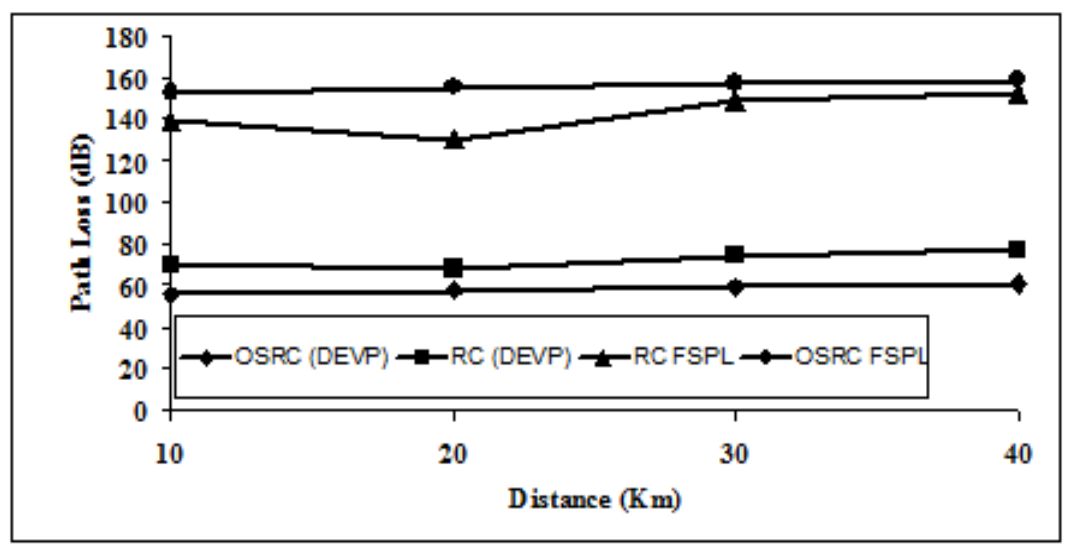

Fig. 9: Comparative performance evaluation of the developed models with FSPL.

To further evaluate and validate the performance of the two developed models, their path losses prediction results were compared with results from recent study in surveyed literature. The choice of the reference study [1] was characterized by: (i) usage of the same existing model in literature; (ii) presence of the same sets of dominant obstructions (buildings and vegetation); and proximity of the study locations. However, there are three differences between the study presented in the paper and reference study. The first is on how the path losses to be compared were determined. While this study used an estimation method through the two developed models, the reference study measured the path losses. The second observed difference is the unit used in measuring the distance. While the distance in the 
study was measured in kilometers $(\mathrm{Km})$, it was measured in meters $(\mathrm{m})$ in the reference study. The third observed difference between the study presented in this paper and reference study is the operating frequency employed. While the frequencies of the transmitters employed in this study are $96.5 \mathrm{MHz}$ and $102.3 \mathrm{MHz}$, the frequency of operation employed in [1] is $2400 \mathrm{MHz}$. However, since the reference study is also a wireless application, the differences in operating frequency will not constitute any con to the validation result. This is because the essence of the validation test is not to compare the result but to show that the result obtained in the study follows the same pattern with other study in literature. The result of the reference study is reproduced and presented graphically in Fig. 10 for easy comparison with the results of this study shown in Fig. 9

Critical observations of Fig. 9 and Fig. 10 show that the results of this study follow the same pattern as other studies in the surveyed literature. The comparative analysis result of Fig. 9 and Fig. 10 also shows that buildings constitute a higher obstruction to radio signal loss or attenuation than vegetation because high buildings are the predominant obstruction in the reference study's area. In addition, the comparative analysis result further shows that path loss is directly proportional to distance. Furthermore, the comparative analysis result establishes the validity of the study presented in this paper as well as confirms that this study's results compare favorably with similar studies in the literature.

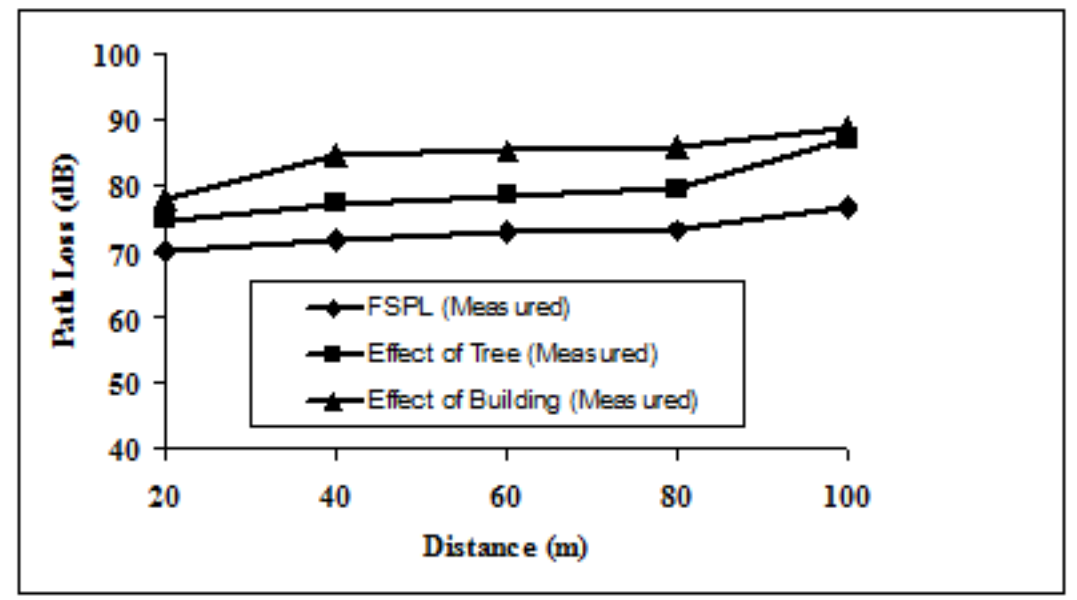

Fig. 10: Predicted path loss for FSPL and developed models at different terrains.

\section{CONCLUSION}

Over the last two decades, tremendous development in wireless or radio communication has led to the emergence of a series of wireless applications and services as well as techniques for improving information transmission and quality of service of wireless communication systems. One such technique is accurate in its modeling of complex radio environments to enhance optimum design and planning of wireless communication systems. In achieving this objective, this paper technically investigates the hypothesis that there is need to develop specific propagation models for specific radio environments. In achieving the objective, the FSPL model was modified to develop two new set of propagation models for the VHF broadcasting band using two FM broadcasting stations as case studies. The developed models were evaluated to determine their performances, which show some level of differences based on the terrain characteristics of the environment in which each of the broadcasting stations employed is located. This confirms the hypothesis for specific model for specific location in order to enhance service planning and quality of service in wireless communication systems. In addition, the path loss prediction results obtained from the two 
developed models show that the two developed models perform favorably well with related studies in literature.

\section{REFERENCES}

[1] Nwawelu UN, Nzeako N, Ahaneku MA. (2012) The limitations of campus wireless networks: A case study of University of Nigeria, Nsukka [Lionet]. Int. J. Networks and Communications, 2(5):112-122.

[2] Zakaria Y, Ivanek L. (2016) Propagation modeling of path loss models for wireless communication in urban and rural environments at 1800 GSM frequency band. Information and Communication Technologies and Services, 14(2):139-144.

[3] Kumari M, Yadav T, Yadav P, Sharma PK, Sharma D. (2011) Comparative study of path loss models in different environments. Int. J. Engineering Science and Technology, 3(4):2945-2949.

[4] Adegoke AS, Siddle D, Salami SO. (2016) Vegetation attenuation and its dependence on foliage density. Eur. J. Enginering and Technology, 4(3):1-7.

[5] Sarkar TK, Ji Z, Kim K, Medouri A, Salazar-Palma M. (2003) A survey of various propagation models for mobile communication. IEEE Antennas and Propagation Magazine, 45(3):51-82.

[6] Faruk N, Ayeni AA, Adeniran YA. (2013) Characterization of propagation path loss at VHF/UHF bands for Ilorin city, Nigeria. Nigerian Journal of Technology, 32(2):253-265.

[7] Song Y, Lee YH, Ng BC. (2009) The effects of tropical weather on radio-wave propgation over foliage channel. IEEE Transactions on Vehicular Technology, 58(8):4023-4030.

[8] Sah N, Thakur T. (2005) Effects of clustters on path loss proposed by Walfisch-Ikegami propagation model. Proceedings of the 11th National Conference on Communications, Kharagpur, India, 28-30 January, 617-620.

[9] Ly PL, Ly PL, Rahman TA, Abu MK. (2010) Investigation ofg foliage effects via remote data logging at 5.8 GHz. WSEAS Transaction on Communications, 9(4):237-247.

[10] Mawjoud SA. (2013) Path loss propagation model prediction for GSM network planning. Int. J. Computer Applications, 84(7):30-33.

[11] Abbaayawardhana VS, Wasell IJ, Crosby D, Sellars MP, Brown MG. (2005) Comparison of emprical propagation path loss models for fixed wireless access systems. Proceedings of the 61 st IEEE Vehicular Technology Conference, Stockholm, Sweden, 30 May-1 June, doi:10 1109/VETECS.2005.1543252.

[12] Sati G, Singh S. (2014) A review on outdoor propagation models in radio communication. Int. J. Computer Engineering and Science, 4(2):64-68.

[13] Famoriji JO, Olasoji YO. (2013) Development of a radiowave propagation model for hillyareas. Int. J. Electronics Communication and Computer Engineering, 4(2):536-539.

[14] Akinbolati A, Akinsanmi O. Ekundayo KR. (2016) Signal strength variation and propagation profiles of UHF radio wave channel in Ondo State, Nigeria. Int. J. Wireless and Mocrowave Technologies, 4:12-28

[15] Mardeni R, Kwan KF. (2010) Optimization of Hata propagation prediction model in suburban area in Malaysia. Progress in Electromagnetic Research C, 13:91-106.

[16] Nissirat L, Ismail M, Nisirat MA. (2012) Macro-cell path loss prediction, calibration, and optimization by Lee's model for South of Amman city, Jordan at 900, and $1800 \mathrm{MHz}$. J. Theoretical and Applied Information Technology, 41(2):253-258.

[17] Bolli S, Khan MZA. (2015) A novel LMMSE based optimized Per-Vega Zamannillo propagation path loss model in UHF/VHF bands for India. Progress in Electromagnetic Research B, 63:17-33

[18] Pathania P, Kumar P, Rana SB. (2014) A modified formulation of path loss models for broadcasting applications. Int. J. Recent Technology and Engineering, 3(3):44-54

[19] Obot A, Simeon O, Afolayan J. (2011) Comparative analysis of path loss prediction models for urban macrocellular environments. Nigerian Journal of Technology, 30(3):50-59. 
[20] Zar PT, Hlaing AS. (2014) Modification of propagation prediction for $2.4 \mathrm{GHz}$ indoor wireless environment. Proceedings of the International Conference on Advances in Engineering and Technology, Singapore, 29-30 March,360-364.

[21] Parsons JD. (2000) The mobile radio propagation channel, Second Edition, John Wiley and Sons Ltd, New York, 1-433. Online [Available]: http://read.pudn.com/downloads114/ebook/480003/Mobile-Radio-Propagation-Channel.pdf. Retrived on October 5, 2017.

[22] Shoewu O, Edeko FO. (2011) Analysis of radio wave propagation in Lagos environs. Am. J. Scientific and Industrial Research, 2(3):438-455.

[23] Podder PK, Islam F, Sarker DK, Hasan MG, Kundu D. (2012) An analysis study for the performance analysis of propagation models in WiMAX. Int. J. Computational Engineering Research, 2(1):175-181.

[24] Rodriguez I, Abreu R, Almeida EPL, Lauridsen M, Loureiro A, Mogensen P. (2016) 24 $\mathrm{GHz} \mathrm{cmWave}$ radio propagation through vegetation: Suburban tree clutter attenuation. Proceedings of 10th IEEE European Conference on Antennas and Propagation, Davos, Swizerland, 10-15 April, DOI:10.1109/EuCAP.2016.7481471.

[25] Milanović J, Rimac-Drlje S, Majerski I. (2010) Radio Wave propagation mechanisms and empirical models for fixed wireless access systems. Technical Gazette, 17(1):43-52.

[26] Temaneh-Nyah C, Nepembe J. (2014) Determination of a suitable correction factor to a radio propagation model for cellular wireless network analysis. 5th Proceedings of IEEE International Conference on Intelligent Systems, Modelling and Simulation, Sheraton Langkawi Beach Resort Teluk Nibong Langkawi, Malaysia, 27-29 January,175-182. 